Published in final edited form as:

Polyhedron. 2013 March 1; 52: 261-267. doi:10.1016/j.poly.2012.09.034.

\title{
Metal complexes with varying intramolecular hydrogen bonding networks
}

\author{
David C. Lacya ${ }^{a}$, Jhumpa Mukherjee ${ }^{a}$, Robie L. Lucas ${ }^{b}$, Victor W. Day ${ }^{b}$, and A.S. Borovik ${ }^{a}{ }^{*}$ \\ aDepartment of Chemistry, University of California-Irvine, 1102 Natural Sciences II, Irvine, CA \\ 92697, United States \\ bDepartment of Chemistry, University of Kansas, Lawrence, KS 66045, United States
}

\begin{abstract}
Alfred Werner described the attributes of the primary and secondary coordination spheres in his development of coordination chemistry. To examine the effects of the secondary coordination sphere on coordination chemistry, a series of tripodal ligands containing differing numbers of hydrogen bond (H-bond) donors were used to examine the effects of H-bonds on Fe(II), Mn(II)acetato, and $\mathrm{Mn}(\mathrm{III})-\mathrm{OH}$ complexes. The ligands containing varying numbers of urea and amidate donors allowed for systematic changes in the secondary coordination spheres of the complexes. Two of the $\mathrm{Fe}$ (II) complexes that were isolated as their $\mathrm{Bu}_{4} \mathrm{~N}^{+}$salts formed dimers in the solidstate as determined by $\mathrm{X}$-ray diffraction methods, which correlates with the number of $\mathrm{H}$-bonds present in the complexes (i.e., dimerization is favored as the number of H-bond donors increases). Electron paramagnetic resonance (EPR) studies suggested that the dimeric structures persist in acetonitrile. The $\mathrm{Mn}$ (II) complexes were all isolated as their acetato adducts. Furthermore, the synthesis of a rare $\mathrm{Mn}$ (III)-OH complex via dioxygen activation was achieved that contains a single intramolecular H-bond; its physical properties are discussed within the context of other $\mathrm{Mn}(\mathrm{III})-\mathrm{OH}$ complexes.
\end{abstract}

\section{Keywords}

Secondary coordination sphere; Hydrogen bonds

\section{Introduction}

Alfred Werner described the primary and secondary coordination spheres in his development of modern inorganic chemistry for which he was awarded the 1913 Nobel prize in chemistry [1]. The primary coordination sphere is concerned with metal-ligand interactions which often govern molecular/electronic structure and reactivity. In the context

\footnotetext{
(C) 2012 Published by Elsevier Ltd.

"Corresponding author. aborovik@uci.edu (A.S. Borovik).

Appendix A. Supplementary data

CCDC 883303, 883304, and 883305 contain the supplementary crystallographic data for $\mathrm{K}\left[\mathrm{Mn}^{\mathrm{III}} \mathrm{H1}(\mathrm{OH})\right] \cdot 1.5 \mathrm{DMA}$, $\left\{\mathrm{Bu} 4 \mathrm{~N}\left[\mathrm{Fe}^{\mathrm{II}} \mathrm{H}_{3} \text { buea }\right] \cdot 2 \mathrm{MeCN}\right\}_{2}$, and $\left\{\mathrm{Bu}_{4} \mathrm{~N}\left[\mathrm{Fe}^{\mathrm{II}} \mathrm{H}_{2} 2\right] \cdot \mathrm{MeCN}\right\}_{2}$. These data can be obtained free of charge via http:// www.ccdc.cam.ac.uk/conts/retrieving.html, or from the Cambridge Crystallographic Data Centre, 12 Union Road, Cambridge CB2 1EZ, UK; fax: (+44) 1223-336-033; or deposit@ ccdc.cam.ac.uk.
} 
of coordination chemistry, the secondary coordination sphere includes the microenvironment around a metal center and does not interact with metal centers through covalent bonds. Rather, the secondary coordination sphere is defined as interactions with ligands or other species within close proximity to the metal ion. The integration of these types of interactions within one molecular species is necessary to fully garner the capabilities of transition metal ions and provides many design challenges to modern inorganic chemists. In particular, the ability to control the secondary coordination sphere with non-covalent interactions has hindered progress in transition metal chemistry.

Several groups have been developing approaches whose aim it is to regulate both the primary and the secondary coordination sphere in synthetic transition metal complexes and proteins [2]. Our strategy involves the synthesis of complexes with intramolecular hydrogen bonds (H-bonds) [3]. The design of our ligands has been influenced by the structures found within the active sites of metal-loproteins that use $\mathrm{H}$-bonds proximal to metal ions to control many aspects of biological coordination chemistry [4]. These aspects range from physical properties such as redox potentials to substrate specificity and activation of small molecules. We have developed a series of tripodal ligands that allows for the systematic variation in of the number of intramolecular H-bond donors while keeping the primary coordination sphere constant (Fig. 1) [5]. These trianionic ligands utilize amidate/ureate groups that promote trigonal bipyramidal coordination geometry and provide $\mathrm{H}$-bonding networks that can contain up to three intramolecular H-bonds. Previous studies have demonstrated how Hbonds affect the activation of dioxygen in cobalt(II) complexes and the physical properties in a series of $\mathrm{Fe}(\mathrm{III})-\mathrm{OH}$ complexes [5]. In this report we examine the chemistry associated with a series of $\mathrm{M}(\mathrm{II})(\mathrm{M}=\mathrm{Mn}, \mathrm{Fe})$ complexes and present evidence that $\mathrm{H}$-bonds can affect solution speciation. We further present the preparation and molecular structure of a new $\mathrm{Mn}(\mathrm{III})-\mathrm{OH}$ complex and compare its structural properties to related complexes using this series of ligands.

\section{Experimental details}

\subsection{General methods}

All chemicals were purchased from commercial sources and used as received unless otherwise noted. Potassium hydride, dispersed in mineral oil, was filtered and washed at least five times with pentane and $\mathrm{Et}_{2} \mathrm{O}$, dried on a vacuum line, and stored under an argon atmosphere. Ferrocenium tetrafluoroborate was synthesized as described by Geiger [6]. Solvents were purified using a JC Meyer Co. solvent purification system. All metal complexes were prepared in a Vacuum Atmospheres Co. dry box with an argon atmosphere. The ligands were prepared according to literature methods [5]. The $\mathrm{K}_{2}\left[\mathrm{Mn}^{\mathrm{II}} \mathrm{H}_{3}\right.$ buea( $\left(\kappa^{1}-\right.$ OAc)] salt was prepared as described by literature methods [7].

[K(18-crown-6) $]_{2}\left[\mathrm{Mn}(\mathrm{II}) \mathrm{H1}\right.$ (OAc)]- $\mathrm{H}_{4} \mathbf{1}$ (100 mg, $\left.0.28 \mathrm{mmol}\right)$ was treated with $\mathrm{KH}$ (34 $\mathrm{mg}, 0.85 \mathrm{mmol})$ in $3 \mathrm{~mL}$ of DMA and allowed to stir until gas evolution ceased $(\sim 1 \mathrm{~h})$. The foamy reaction mixture was treated with $\mathrm{Mn}(\mathrm{OAc})_{2}(48 \mathrm{mg}, 0.28 \mathrm{mmol})$ and allowed to stir for $2 \mathrm{~h}$ during which potassium acetate precipitated and was removed by filtration with a medium porosity glass fritted funnel. The filtrate was treated with 18-crown-6 $(150 \mathrm{mg}, 0.57$ mmol) and stirred until completely dissolved. The solvent was removed under reduced 
pressure and the resulting white residue was treated with $\mathrm{Et}_{2} \mathrm{O}$ until a white precipitate persisted, which was then collected on a glass fritted funnel and dried for $1 \mathrm{~h}$ under vacuum to yield a free flowing white powder $\left(232 \mathrm{mg}, 71 \%\right.$ ). FTIR (Nujol, $\left.\mathrm{cm}^{-1}\right)$ v(NH) 3373, 3170; $v$ (CO) 1641, 1552. Anal. Calc. for [K(18-crown-6) $]_{2}\left[\mathrm{Mn}^{\mathrm{II}} \mathrm{H1}(\mathrm{OAc})\right] \cdot \mathrm{DMA}$, $\mathrm{C}_{47} \mathrm{H}_{92} \mathrm{~K}_{2} \mathrm{MnN}_{6} \mathrm{O}_{18}: \mathrm{C}, 48.31 ; \mathrm{H}, 8.09 ; \mathrm{N}, 7.59$. Found: C, 48.56; H, 7.98; N, 7.23\%. Xband EPR (DMSO, $77 \mathrm{~K}) \mathrm{g}=23.45,4.39,3.12,2.46,1.96$.

[K(18-crown-6) $]_{2}\left[\mathrm{Mn}^{\| 1} \mathrm{H}_{\mathbf{2}} \mathbf{2}(\mathrm{OAc})\right]-T h e$ same procedure for preparation of [[K(18crown-6) $]_{2}\left[\mathrm{Mn}{ }^{\mathrm{II}} \mathrm{H1}(\mathrm{OAc})\right]$ was followed using $\mathrm{H}_{5} 2$ (100 mg, $\left.0.25 \mathrm{mmol}\right), \mathrm{KH}$ (30 mg, 0.75 $\mathrm{mmol}), \mathrm{Mn}(\mathrm{OAc})_{2}(43 \mathrm{mg}, 0.25 \mathrm{mmol})$, and 18-crown-6 (13 mg, $\left.0.50 \mathrm{mmol}\right)$ to afford 280 mg (44\%) of the desired salt. ESIMS ( $/ \mathrm{m} / \mathrm{z}): 452.2\left[\mathrm{Mn}^{\mathrm{II}} \mathrm{H}_{2} 2\right]^{-} ; 512.3\left[\mathrm{Mn}^{\mathrm{II}} \mathrm{H}_{2} 2(\mathrm{OAc})\right]^{-}$. Anal. Calc. for [K(18-crown-6) $]_{2}\left[\mathrm{Mn}^{\mathrm{II}} \mathrm{H}_{2} 2\right.$ (OAc)].DMA, $\mathrm{C}_{49} \mathrm{H}_{97} \mathrm{~K}_{2} \mathrm{MnN}_{7} \mathrm{O}_{18}: \mathrm{C}, 48.88 ; \mathrm{H}$, 8.33; N, 8.10. Found: C, 48.82; H, 8.11; N, 8.13\%. X-band EPR (DMA, 77 K) 28.45, 5.90, $3.06,2.48,1.96$.

[K(18-crown-6) $]_{2}\left[\mathrm{Mn}(\mathrm{II}) 0^{\mathrm{cyp}}(\mathrm{OAc})\right]$-The same procedure for preparation of $[\mathrm{K}(18$ crown-6) $]_{2}\left[\mathrm{Mn}^{\mathrm{II}} \mathrm{H} \mathbf{1}^{\mathrm{iPr}}(\mathrm{OAc})\right]$ was followed using $\mathrm{H}_{3} \mathbf{0}^{\text {cyp }}$ (100 mg, $\left.0.26 \mathrm{mmol}\right), \mathrm{KH}(31 \mathrm{mg}$, $0.77 \mathrm{mmol}), \mathrm{Mn}(\mathrm{OAc})_{2}(44 \mathrm{mg}, 0.26 \mathrm{mmol})$, and 18 -crown-6 (140 mg, $\left.0.53 \mathrm{mmol}\right)$ to yield $220 \mathrm{mg}(73 \%)$ of the desired salt. FTIR (Nujol, $\mathrm{cm}^{-1}$ ) $v(\mathrm{NH}) 3165$; $v(\mathrm{CO}) 1646,1554$. Anal. Calc. for [K(18-crown-6) $]_{2}\left[\mathrm{Mn}^{\mathrm{II}}{ }^{\text {cyp }}(\mathrm{OAc})\right] \cdot \mathrm{DMA}, \mathrm{C}_{51} \mathrm{H}_{93} \mathrm{~K}_{2} \mathrm{MnN}_{5} \mathrm{O}_{18}$ : C, 51.47; H, 8.01; N, 5.65. Found: C, 51.15; H, 7.83; N, 5.85\%. X-band EPR (DMSO, $77 \mathrm{~K}$ ) $g=15.59,5.61$, $3.88,2.87,2.33,1.91$.

[K(18-crown-6) $]_{2}\left[\mathrm{Mn}(\mathrm{II}) \mathbf{0}^{\mathrm{ipr}}(\mathrm{OAc})\right]$ - The same procedure for preparation $[\mathrm{K}(18$ crown-6) $]_{2}\left[\mathrm{Mn}^{\mathrm{II}} \mathrm{H1}(\mathrm{OAc})\right]$ was followed using $\mathrm{H}_{3} \mathbf{0}^{\mathrm{ipr}}$ (100 mg, $\left.0.32 \mathrm{mmol}\right), \mathrm{KH}$ (38 mg, $0.96 \mathrm{mmol}), \mathrm{Mn}(\mathrm{OAc})_{2}(55 \mathrm{mg}, 0.32 \mathrm{mmol})$, and 18-crown-6 (170 mg, $\left.0.64 \mathrm{mmol}\right)$ to produce $220 \mathrm{mg}(68 \%)$ of the desired salt. FTIR (Nujol, $\left.\mathrm{cm}^{-1}\right)$ v(NH) 3168; v(CO) 1647, 1553. Anal. Calc. for [K(18-crown-6) $]_{2}\left[\mathrm{Mn}^{\mathrm{II}} \mathbf{0}^{\mathrm{ipr}}(\mathrm{OAc})\right], \mathrm{C}_{41} \mathrm{H}_{78} \mathrm{~K}_{2} \mathrm{MnK}_{2} \mathrm{~N}_{4} \mathrm{O}_{17}$ : C, 47.76; H, 7.89; N, 5.62. Found: C, 47.71; H, 7.62; N, 5.43\%. X-band EPR (DMA, 77 K) $g=16.18$, $5.98,3.94,2.95,2.44,2.97$.

$\left[\mathrm{Bu}_{4} \mathrm{~N}\right]_{2}\left[\mathrm{Fe}(\mathrm{II}) \mathrm{H}_{3} \text { buea }\right]_{2}$-A solution of $\mathrm{H}_{6}$ buea $(200 \mathrm{mg}, 0.45 \mathrm{mmol})$ dissolved in $4 \mathrm{~mL}$ of anhydrous DMA was treated with solid KH $(55 \mathrm{mg}, 1.36 \mathrm{mmol})$ and stirred until gas evolution ceased. $\mathrm{Fe}(\mathrm{OAc})_{2}(79 \mathrm{mg}, 0.45 \mathrm{mmol})$ was added to the pale yellow solution, and stirring was continued for $30 \mathrm{~min}$. The resulting amber filtrate was treated with $\left[\mathrm{Bu}_{4} \mathrm{~N}\right]$ [OAc] (140 mg, $0.45 \mathrm{mmol}$ ) and stirred for $2 \mathrm{~h}$, resulting in the precipitation of a white solid (305 mg) that was filtered, washed twice with $\mathrm{Et}_{2} \mathrm{O}$, and dried under vacuum. The white solid was stirred in $\mathrm{CH}_{3} \mathrm{CN}$ for $1 \mathrm{~h}$ and filtered to remove $\mathrm{KOAc}(105 \mathrm{mg}, 96 \%)$. The light yellow filtrate was concentrated to half its original volume and the slow addition of $\mathrm{Et}_{2} \mathrm{O}$ resulted in the formation of a white solid, which was then filtered, washed with $\mathrm{Et}_{2} \mathrm{O}$, and dried under vacuum to afford $150 \mathrm{mg}(47 \%)$ of the desired salt. Anal. Calc. for $\left[\mathrm{Bu}_{4} \mathrm{~N}\right]_{2}\left[\mathrm{Fe}^{\mathrm{II}} \mathrm{H}_{3} \text { buea }\right]_{2}, \mathrm{C}_{74} \mathrm{H}_{156} \mathrm{Fe}_{2} \mathrm{~N}_{16} \mathrm{O}_{6}: \mathrm{C}, 60.14 ; \mathrm{H}, 10.64 ; \mathrm{N}, 15.16$. Found: $\mathrm{C}, 61.19$; $\mathrm{H}, 10.89 ; \mathrm{N}, 15.68 \%$. FTIR (Nujol, $\mathrm{cm}^{-1}$ ) $v(\mathrm{NH}) 3335, v(\mathrm{CO})$ 1663, 1592, 1571, 1556. Single crystals were grown by diffusion of $\mathrm{Et}_{2} \mathrm{O}$ into a $\mathrm{CH}_{3} \mathrm{CN}$ solution of the crude complex. 
$\left[\mathrm{Bu}_{4} \mathrm{~N}_{2}\left[\mathrm{Fe}(\mathrm{II}) \mathrm{H}_{2} 2^{i \mathrm{Pr}}\right]_{2}\right.$ was prepared following a similar procedure to that of $\left[\mathrm{Bu}_{4} \mathrm{~N}\right]_{2}\left[\mathrm{Fe}(\mathrm{II}) \mathrm{H}_{3} \text { buea }\right]_{2}$ with $\mathrm{H}_{5} 2^{\mathrm{iPr}}(150 \mathrm{mg}, 0.37 \mathrm{mmol}), \mathrm{KH}(45 \mathrm{mg}, 1.12 \mathrm{mmol})$, $\mathrm{Fe}(\mathrm{OAc})_{2}(66 \mathrm{mg}, 0.37 \mathrm{mmol})$, and $\left[\mathrm{Bu}_{4} \mathrm{~N}\right][\mathrm{OAc}](113 \mathrm{mg}, 0.37 \mathrm{mmol})$. The amount of KOAc obtained was $105 \mathrm{mg}$ (96\% for 3 equiv) and $100 \mathrm{mg}(42 \%)$ of $\left[\mathrm{Bu}_{4} \mathrm{~N}\right]_{2}\left[\mathrm{Fe}^{\mathrm{II}} \mathrm{H}_{2} 2^{\mathrm{iPr}}\right]$ was isolated. Single crystals were grown by diffusion of $\mathrm{Et}_{2} \mathrm{O}$ into a $\mathrm{CH}_{3} \mathrm{CN}$ solution of the complex. FTIR (Nujol, $\mathrm{cm}^{-1}$ ) v(NH) 3332, v(CO) 1661, 1590, 1561, 1520. Repeated attempts to obtain a satisfactory elemental analysis were unsuccessful.

$\mathbf{K}_{\mathbf{2}}[\mathbf{M n}(\mathrm{II}) \mathbf{H} \mathbf{1}(\mathrm{OH})]-\mathrm{H}_{\mathbf{4}} \mathbf{1}(0.050 \mathrm{mg}, 0.14 \mathrm{mmol})$ was deprotonated with 4 equiv $\mathrm{KH}$ (23 $\mathrm{mg}, 0.57 \mathrm{mmol}$ ) in $3 \mathrm{~mL}$ of DMA and allowed to stir for $4 \mathrm{~h}$. To the thick foamy suspension was added $\mathrm{Mn}(\mathrm{OAc})_{2}(26 \mathrm{mg}, 0.15 \mathrm{mmol})$ after which the reaction mixture was stirred for $30 \mathrm{~min} . \mathrm{H}_{2} \mathrm{O}(2.5 \mu \mathrm{L}, 0.14 \mathrm{mmol})$ was added and allowed to stir for $30 \mathrm{~min}$. The mixture was filtered and the resulting DMA solution was allowed for slow vapor diffusion of $\mathrm{Et}_{2} \mathrm{O}$ yielding a white microcrystalline solid, which after several days was isolated on a fritted glass funnel and washed $3 \times 3 \mathrm{~mL} \mathrm{MeCN}, 3 \times 5 \mathrm{~mL} \mathrm{Et}_{2} \mathrm{O}(32 \mathrm{mg}, 46 \%)$. FTIR (Nujol, $\mathrm{cm}^{-1}$ ) $v(\mathrm{OH}) 3503$; $v(\mathrm{NH}) 3244,3142$; $v(\mathrm{CO}) 1655,1567,1507$. Anal. Calc. for $\mathrm{K}_{2}\left[\mathrm{Mn}{ }^{\mathrm{II}} \mathrm{H1}(\mathrm{OH})\right] \cdot 0.5 \mathrm{DMA}, \mathrm{C}_{19} \mathrm{H}_{37.5} \mathrm{~K}_{2} \mathrm{MnN}_{5.5} \mathrm{O}_{4.5}$ : C, 41.93; H, 7.37; N, 13.65. Found: $\mathrm{C}$, 41.63; H, 6.89; N, 14.05\%. X-band EPR (DMF, $77 \mathrm{~K}) g=14.32,5.81,1.99,1.55,1.28$.

$\mathbf{K}[\mathbf{M n}(\mathrm{III}) \mathbf{H} \mathbf{1}(\mathbf{O H})]$-Method A. $\mathrm{H}_{4} \mathbf{1}(110 \mathrm{mg}, 0.30 \mathrm{mmol})$ was dissolved in $3 \mathrm{~mL}$ of DMA and treated with $\mathrm{KH}(36 \mathrm{mg}, 0.90 \mathrm{mmol})$ and the reaction mixture was allowed to stir. After $\sim 19 \mathrm{~h}$ the reaction mixture was treated with $\mathrm{Mn}(\mathrm{OAc})_{2}(51 \mathrm{mg}, 0.29 \mathrm{mmol})$ and stirred for an addition $1 \mathrm{~h}$, after which the reaction was filtered to remove 1 equiv of KOAc (26 mg, $91 \%)$. The pale yellow filtrate was treated with $\mathrm{O}_{2}(7.2 \mathrm{~mL}, 0.29 \mathrm{mmol}, 298 \mathrm{~K}, 1 \mathrm{~atm})$ causing an immediate color change to dark forest green, which slowly turned brownish green. After stirring for an additional $1 \mathrm{~h}$ the system was evacuated to remove excess $\mathrm{O}_{2}$ and brought back into an anaerobic drybox. The solvent was removed under reduced pressure and the resulting residue was extracted with $\mathrm{MeCN}(1 \mathrm{~mL})$ and DMA $(1 \mathrm{~mL})$ and passed through a fritted glass funnel to remove a second equiv of KOAc. The green filtrate was concentrated to less than $1 \mathrm{~mL}$ and $\mathrm{Et}_{2} \mathrm{O}$ was added to precipitate the salt, which was collected on a fritted glass funnel. A brown species was removed from the crude green solid by washing up to $3 \times 0.5 \mathrm{~mL}$ DMA (or until washings did not have a brown color) leaving behind a teal green solid. The teal green solid was washed with $\mathrm{Et}_{2} \mathrm{O}$ and dried under reduced pressure for $1 \mathrm{~h}$ ( $23 \mathrm{mg}, 16 \%$ yield). X-ray quality crystals were obtained by dissolving the teal green solid in $\sim 2 \mathrm{~mL}$ of DMA and diffusing $\mathrm{Et}_{2} \mathrm{O}$. FTIR (Nujol, $\mathrm{cm}^{-1}$ ) $v(\mathrm{OH}) 3645 ; v(\mathrm{NH}) 3278,3175 ; v(\mathrm{CO}) 1634,1596,1582,1533$. UV-Vis $\lambda_{\max }$ (DMA or DMSO, nm $\left.\left(\varepsilon, \mathrm{M}^{-1} \mathrm{~cm}^{-1}\right)\right) 420 \mathrm{~nm}(450), 675 \mathrm{~nm}$ (590). Anal. Calc. for K[Mn $\left.{ }^{\mathrm{III}}-\mathrm{H1}(\mathrm{OH})\right]$, $\mathrm{C}_{17} \mathrm{H}_{33} \mathrm{KMnN}_{5} \mathrm{O}_{4}$ : C, 43.86; H, 7.15; N, 15.04. Found: C, 43.58; H, 7.24; N, 14.29\%. Method B. $\mathrm{K}_{2}\left[\mathrm{Mn}{ }^{\mathrm{II}} \mathrm{H1}(\mathrm{OH})\right](50 \mathrm{mg}, 0.10 \mathrm{mmol})$ was dissolved in $6 \mathrm{~mL}$ of DMA to afford a $17 \mathrm{mM}$ soluton. A $5 \mathrm{~mL}$ portion of the stock solution $(0.083 \mathrm{mmol})$ was treated with solid $\left[\mathrm{FeCp}_{2}\right] \mathrm{BF}_{4}(19 \mathrm{mg}, 0.070 \mathrm{mmol})$ causing the immediate color change from colorless to forest green whose spectroscopic features matched those of $\mathrm{K}\left[\mathrm{Mn}{ }^{\mathrm{III}} \mathrm{H} 1(\mathrm{OH})\right]$ prepared from $\mathrm{O}_{2}$. 


\subsection{Physical methods}

FTIR spectral data were collected using a Varian 800 FTIR Scimitar Series spectrometer. Absorption spectra were collected using a Cary 50 Scan UV-Vis spectrophotometer. Parallel-mode X-band electron paramagnetic resonance (EPR) spectra were collected using a Bruker EMX spectrometer equipped with an ER041XG microwave bridge, an ER4116DM dual-mode cavity, and an Oxford Instrument liquid He quartz cryostat. All EPR spectra were recorded at $10 \mathrm{~K}$ and unless otherwise stated EPR experiments were conducted using the following instrument parameters:modulation amplitude $9.02 \mathrm{G}$; power $0.64 \mathrm{~mW}$. Electrospray mass spectra were collected using a Waters Micromass LCT Premier Mass Spectrometer.

\subsection{Crystallography}

Crystals were attached to a glass fiber and mounted under nitrogen on a Bruker SMART APEX CCD Single Crystal Diffraction System. Full hemisphere of diffracted intensities were measured for a single domain specimen using graphite-monochromated MoKa radiation $(\lambda=0.71073 \AA$ ). $\mathrm{X}$-rays were provided by a fine-focus sealed X-ray tube operated at $50 \mathrm{kV}$ and $30 \mathrm{~mA}$. The structures were solved using direct methods and all stages of the weighted full-matrix least-square refinements were conducted using $F_{\mathrm{o}}^{2}$ data. Crystal data and refinement information for crystal structures can be found in Table 1.

\section{Results and discussion}

\subsection{Synthesis of the $M(I I)$ complexes}

Preparation of the $\mathrm{Mn}^{\mathrm{II}}$ complexes was accomplished by deprotonation of the appropriate tripodal precursor with 3 equiv of KH in DMA to obtain the tri-anionic ligand, which was subsequently treated with $\mathrm{Mn}(\mathrm{II})(\mathrm{OAc})_{2}$. Purification of these $\mathrm{Mn}$ (II) complexes was facilitated by the precipitation of 1 equiv of KOAc (>90\%) because this salt has limited solubility in DMA. The nearly quantitative isolation of only 1 equiv of KOAc suggested that the other equivalent of acetate is coordinated to the $\mathrm{Mn}$ (II) centers in each complex, as we have previously observed in $\left[\mathrm{Mn}(\mathrm{II}) \mathrm{H}_{3} \text { buea }\left(\kappa^{1}-\mathrm{OAc}\right)\right]^{2-}[7]$. The coordination mode is still unknown, but we propose that the acetate would also bind in a similar monodentate manner. We found that the $\mathrm{Mn}$ (II) complexes could be more readily purified as either their $\mathrm{Me}_{4} \mathrm{~N}^{+}$or $\left[(\mathrm{K} \subset \text { 18-crown-6) }]^{+}\right.$salts. Repeated attempts to grow single crystals of each salt that were suitable for X-ray diffraction analysis were unsuccessful. However, elemental and mass spectral data support the premise that one acetate remains bound to the manganese ion. ${ }^{1}$

The Mn(II) complexes of these ligands have different coordination properties with acetate than their $\mathrm{Co}(\mathrm{II})$ and $\mathrm{Fe}(\mathrm{II})$ analogs. Treating either $\left[\mathrm{H}_{3} \text { buea }\right]^{3-},\left[\mathrm{H}_{2} 2\right]^{3-},[\mathrm{H1}]^{3-}$, and $[0]^{3-}$ with $\mathrm{Co}(\mathrm{OAc})_{2}$ or $\mathrm{Fe}(\mathrm{OAc})_{2}$ under the same experimental conditions produced the corresponding metal complexes and 2 equiv of KOAc [5]. Furthermore, spectroscopic and analytical properties of these $\mathrm{Co}$ (II) and $\mathrm{Fe}$ (II) complexes gave no indication that acetate was coordinated to the metal centers. For example, we have reported the molecular structures of $\left[\mathrm{M}(\mathrm{II}) \mathbf{0}^{\mathrm{ipr}}\right]^{-}(\mathrm{M}(\mathrm{II})=\mathrm{Co}$ and $\mathrm{Fe}),\left[\mathrm{Co}(\mathrm{II}) \mathrm{H}{ }^{\mathrm{PPr}}\right]^{-}$, and $\left[\mathrm{CoH}_{2} 2^{\mathrm{iPr}}\right]^{-}$and found

\footnotetext{
${ }^{1}$ See experimental conditions for EA and mass spectral results.
} 
that all have similar trigonal monopyramidal coordination geometry $[5 \mathrm{a}, 8]$. The reason(s) for this difference in acetate binding is still unknown.

In the course of our studies we found that changing the counterions of $\left[\mathrm{Fe}(\mathrm{II}) \mathrm{H}_{3} \text { buea }\right]^{-}$and $\left[\mathrm{Fe}(\mathrm{II}) \mathrm{H}_{2} 2\right]^{-}$from potassium to $\mathrm{Bu}_{4} \mathrm{~N}^{+}$produced salts that were soluble in a range of solvents, including acetonitrile that allowed for the growth of single crystals. Moreover, the $\mathrm{Bu}_{4} \mathrm{~N}^{+}$salt had different EPR and FTIR properties from its potassium analog, suggesting the possibility that a change in structure may have occurred. Our solid state structural studies support this premise, in that this salt crystallized with the $\left[\mathrm{Fe}(\mathrm{II}) \mathrm{H}_{3} \text { buea }\right]_{2}{ }^{2-}$ dimer (Fig. 2).

\subsection{Solid-state structures of $\left[\mathrm{Fe}(\mathrm{II}) \mathrm{H}_{3} \text { buea }\right]_{2}{ }^{2-}$ and $\left[\mathrm{Fe}(\mathrm{II}) \mathrm{H}_{2} 2\right]_{2}{ }^{2-}$}

The solid-state structures of $\left[\mathrm{Bu}_{4} \mathrm{~N}\right]_{2}\left[\mathrm{Fe}(\mathrm{II}) \mathrm{H}_{3} \text { buea }\right]_{2}$ and $\left[\mathrm{Bu}_{4}-\mathrm{N}\right]_{2}\left[\mathrm{Fe}(\mathrm{II}) \mathrm{H}_{2} 2\right]_{2}$ were examined using X-ray diffraction methods and views of the anions are shown in Figs. 2 and 4. Selected bond length and angles can be found in Table 2. The overall lattice structures contained disordered solvent molecules that we were not able to model. However, the anions in the structures of both salts are of high enough quality for us to comment on the primary and secondary spheres about the iron centers. In $\left[\mathrm{Fe}(\mathrm{II}) \mathrm{H}_{3} \text { buea }\right]_{2}{ }^{2-}$ each iron center has an $\mathrm{N}_{4} \mathrm{O}$ primary coordination sphere that are related by a center of symmetry. There are no other exogenous ligands bonded to the iron center with the $\left[\mathrm{H}_{3} \text { buea }\right]^{3-}$ ligands providing all the donor atoms. Each $\left[\mathrm{H}_{3} \text { buea }\right]^{3-}$ ligand coordinates as a tridentate ligand to one iron centers, binding through the apical $\mathrm{N} 1$ atom and the deprotonated ureate nitrogen atoms N2 and N3. The Fe-N1 bond length of 2.270(1) $\AA$ and the Fe-N2 and Fe-N3 bond distances of 2.034 (1) and 2.030 (1) $\AA$ are similar to what we have observed with other Fe(II) complexes having ureate/amine donors $[5 b, 8,9]$. A striking feature of this complex is that the tripodal arm containing N4 does not interact with the same iron center as N1, N2, and N3. Rather, this remaining arm is splayed toward the second iron center, to which it coordinates through both $\mathrm{N} 4$ and $\mathrm{O} 3$ of the urea group. The Fe-N4 bond length of 2.041(1) $\AA$ is statistically different from the other $\mathrm{Fe}-\mathrm{N}_{\text {urea }}$ bond distances and the $\mathrm{Fe}-\mathrm{O} 3$ bond distance of 2.388(1) $\mathrm{A}$ is significantly longer. The $\mathrm{N} 2-\mathrm{Fe}-\mathrm{N} 4$ and $\mathrm{N} 3-\mathrm{Fe}-\mathrm{N} 4$ bond angles are $\sim 122^{\circ}$, whereas N2$\mathrm{Fe}-\mathrm{N} 3$ bond angle is significantly shorter at $115.08(6)^{\circ}$. In addition, the $\mathrm{O} 3-\mathrm{Fe}-\mathrm{N} 1$ bond angle is only $166.70(5)^{\circ}$. Taken together, these metrical results suggest the overall primary coordination sphere is best described as distorted trigonal bipyramidal and is supported by an index of trigonality parameter $(\tau)$ of 0.74 [10].

The secondary coordination sphere is dominated by a H-bond network between $\mathrm{O} 3$ of the extended urea and the NH groups containing N5 and N6. Two intramolecular H-bonds are formed with $\mathrm{N} 5 \cdots \mathrm{O} 3$ and $\mathrm{N} 6 \cdots \mathrm{O} 3$ distances of 3.148 and $3.012 \AA$. These distances are slightly longer that what is normally observed with other ligands within this type of $\mathrm{H}$ bonding cavity. However, the relatively longer $\mathrm{Fe}-\mathrm{O} 3$ bond length is undoubtedly caused, in part, to the H-bonds surrounding the urea group. This unsymmetrical coordination of the urea is similar to what we have observed with other bidentate anions to iron, such as acetate. In fact, the coordination spheres in $\left[\mathrm{Fe}(\mathrm{II}) \mathrm{H}_{3} \text { buea }\right]_{2}{ }^{2-}$ are analogous to the $\mathrm{Fe}$ (II)-acetato complex with the tridentate ligand bis[( $N^{\prime}$-tert-butylureido)- $N$-ethyl $]-N$-methylamine $\left(\left[\mathrm{H}_{2} \text { buma }\right]^{2-} \text {, Fig. 3) [11]. Note that in [Fe(II) } \mathrm{H}_{2} \text { buma }\left(\kappa^{2}-\mathrm{OAc}\right)\right]^{2-}$ the acetate coordinates in a unsymmetrical manner and only one of its oxygen atoms is involved in $\mathrm{H}$-bonding. 
The molecular structure of $\left[\mathrm{Fe}^{\mathrm{II}} \mathrm{H}_{2} 2\right]_{2}{ }^{2-}$ possessed many aspects that were found in $\left[\mathrm{Fe}(\mathrm{II}) \mathrm{H}_{3} \text { buea }\right]^{2-}$ (Fig. 4). The $\left[\mathrm{H}_{2} 2\right]^{3-}$ ligand also spans two metal centers, with one urea arm binding in a bidentate mode to a second iron. The iron centers have $\mathrm{N}_{4} \mathrm{O}$ primary coordination spheres with distorted trigonal bipyramidal geometries $(\tau=0.71)$. The main difference between the two structures is in their secondary coordination sphere because $\left[\mathrm{H}_{2} 2\right]^{3-}$ only provided a single H-bond donor. Thus each bidentate urea group has an N5$\mathrm{H} 5 \cdots \mathrm{O} 3$ interaction with an $\mathrm{N} 5 \cdots \mathrm{O}$ separation of $2.903 \AA$. The presence of only one $\mathrm{H}$ bond also results in a slight, but statistically significant, shortening of the $\mathrm{Fe}-\mathrm{O} 3$ bond length to 2.335(2) $\AA$. In addition, the $\mathrm{Fe} \cdots \mathrm{Fe}$ separation is shortened to 5.950(2) $\AA$ in $\left[\mathrm{FeH}_{2} 2\right]_{2}{ }^{2-}$ from 6.119(1) $\AA$ in [Fe(II) $\mathrm{H}_{3}$ buea $]_{2}{ }^{2-}$.

We have obtained several molecular structures of metal complexes with $\left[\mathrm{H}_{3} \text { buea }\right]^{3-}$ and all were monomeric species with the three arms of the tripod coordinated to the same metal ion.

The molecular structure of $\left[\mathrm{Fe}(\mathrm{II}) \mathrm{H}_{3} \text { buea }\right]_{2}{ }^{2-}$ represents a new binding mode in which one arm from $\left[\mathrm{H}_{3} \text { buea }\right]^{3-}$ coordinated to another species (in this case, a second $\left[\mathrm{Fe}(\mathrm{II}) \mathrm{H}_{3}\right.$ buea ${ }^{-}$ complex). Our earlier systems are different in that they had an exogenous ligand within cavity that was able to form H-bonds $[9,12]$. We have shown that the urea cavity formed by $\left[\mathrm{H}_{3} \text { buea }\right]^{3-}$ has a strong propensity to form H-bonds, which we have used to prepare a variety of monomeric, five-coordinate hydroxo and oxo complexes. In the absence of an exogenous fifth ligand, it appears that the complex is capable of reorganizing to adopt a trigonal bipyramidal coordination that places a ligand (e.g., a mono-deprotonated urea group) that binds to the iron center and forms H-bonds. Another difference is the use of $\mathrm{Bu}_{4} \mathrm{~N}^{+}$as the counterion instead of potassium ions as we have done in the past. It is not known how the change in counterion effects this type of chemistry-we have never been able to structurally characterized a potassium salt for a complex with $\left[\mathrm{H}_{3} \text { buea }\right]^{3-}$ that does not have an exogenous ligand presence within the H-bonding cavity.

The structure of $\left[\mathrm{Fe}(\mathrm{II}) \mathrm{H}_{2} 2\right]_{2}{ }^{2-}$ showed that this ligand can also form dimeric complexes in the absence of an exogenous ligand. However, we are unsure whether this type of coordination chemistry can be extended to other metal ions. As mentioned above, structural studies on $\mathrm{K}\left[\mathrm{CoH}_{2} 2\right]$ revealed that all three arms of the tripod are coordinated to the same $\mathrm{Co}(\mathrm{II})$ center [5a]. In addition, we have structurally characterized $\mathrm{K}[\mathrm{Fe}(\mathrm{II}) \mathbf{0}]$ and $\mathrm{K}[\mathrm{Co}(\mathrm{II}) \mathbf{0}]$, and found that both complexes are monomeric with a trigonal monopyramidal coordination geometry $[5 a, 8]$.

\subsection{EPR studies on the Fe(II) complex}

We have investigated the solution speciation of these Fe(II) complexes using EPR spectroscopy. All the complexes are high spin with $S=2$ spin ground states. Conventional perpendicular-mode X-band EPR spectroscopy was not helpful in this study because integer spin systems are typically not detectable. We have thus turned to parallel-mode ( $\|$-mode) methods, which can be used to observe transitions from species within an $S=2$ spin manifold. For the present study, we are using this method to qualitatively investigate these types of $\mathrm{Fe}(\mathrm{II})$ complexes. 
The low temperature (4 K) $\|$-mode EPR spectrum for a frozen DMA solution of $\mathrm{K}[\mathrm{Fe}(\mathrm{II}) \mathbf{0}]$ displayed a relative broad feature at a $g$-value of 9.2 (Fig. 5). Signals with similar $g$-values have been reported for other monomeric high-spin Fe(II) complexes [12b]. A slightly broader spectrum at $g=8.8$ was obtained for a solid sample of this salt, suggesting that the electronic and molecular structures of the $\mathrm{Fe}(\mathrm{II})$ species in the solid-state and solution are similar. Because we have determined that $[\mathrm{Fe}(\mathrm{II}) \mathbf{0}]^{-}$is a monomer in the solid state, we propose that the complex remains monomeric in solution. In our own studies, we have used this signal as a reference for monomeric Fe(II) species to help probe the speciation of the other complexes in solution.

The $\|$-mode EPR spectra for solid samples of $\left[\mathrm{Bu}_{4} \mathrm{~N}_{2}\left[\mathrm{Fe}(\mathrm{II}) \mathrm{H}_{3} \text { buea }\right]_{2}\right.$ had a broad feature at $g=16$ and a shoulder centered at $g=22$ (Fig. 6A), features that are assigned to the dimeric complexes identified by X-ray diffraction methods. Frozen $\mathrm{CH}_{3} \mathrm{CN}$ solution of $\left[\mathrm{Bu}_{4} \mathrm{~N}\right]_{2}\left[\mathrm{Fe}(\mathrm{II}) \mathrm{H}_{3} \text { buea }\right]_{2}$ gave $\|$-mode EPR spectra that had a similar broad peak centered at $g=15$. There is also a small shoulder at $g=11$ that could be caused by a small amount of monomeric $\mathrm{Fe}(\mathrm{II})$ complex being present (i.e., $\left[\mathrm{Fe}(\mathrm{II}) \mathrm{H}_{3} \text { buea }\right]^{-}$). Nevertheless, the similarities between the solid-state and frozen solution spectra indicate that the dimeric $\left[\mathrm{Fe}(\mathrm{II}) \mathrm{H}_{3} \text { buea }\right]_{2}{ }^{2-}$ complex remains the predominate $\mathrm{Fe}(\mathrm{II})$ species in acetonitrile. $\left[\mathrm{Fe}(\mathrm{II}) \mathrm{H}_{2} 2\right]_{2}{ }^{2-}$ also appears to remain a dimer in solution as the $\|$-mode EPR spectrum for a frozen acetonitrile solution of $\left[\mathrm{Bu}_{4} \mathrm{~N}\right]_{2}\left[\mathrm{Fe}(\mathrm{II}) \mathrm{H}_{2} 2\right]_{2}$ also has a peak at $g=16$ and shoulder at $g=9.0$ (Fig. 6B). Notice that the solid-state spectrum is comparable with features at $g$ values of 21 and $\sim 10$.

\subsection{Preparation of $[\mathrm{Mn}(\mathrm{III}) \mathrm{H1}(\mathrm{OH})]^{-}$}

We have previously reported the preparation and structural characterization of $\mathrm{K}\left[\mathrm{Mn}(\mathrm{III}) \mathrm{H}_{3}\right.$ buea( $\left.(\mathrm{OH})\right]$ and $\mathrm{K}[\mathrm{Mn}(\mathrm{III}) \mathbf{0}(\mathrm{OH})]$ and found that the anions of each salt were monomeric with trigonal bipyramidal coordination geometry $[7,12 b, 13]$. The related $\mathrm{Mn}(\mathrm{III})-\mathrm{OH}$ complex with [H1 $]^{3-}$ has now been prepared, using a procedure in which $\mathrm{K}_{2}\left[\mathrm{Mn}{ }^{\mathrm{II}} \mathrm{H1}(\mathrm{OAc})\right]$ was oxidized with dioxygen (Scheme 1$) .{ }^{2}$ FTIR spectroscopy was used to analyze the energies of the $\mathrm{O}-\mathrm{H}$ vibrations in the $\mathrm{Mn}(\mathrm{III})-\mathrm{OH}$ complex. The $\mathrm{O}-\mathrm{H}$ vibration for $[\mathrm{Mn}(\mathrm{III}) \mathrm{H1}(\mathrm{OH})]^{-}$was found at $v(\mathrm{O}-\mathrm{H})=3644 \mathrm{~cm}^{-1}$, which is the same within experimental error to the value reported for $[\mathrm{Mn}(\mathrm{III}) \mathbf{0}(\mathrm{OH})]^{-}\left(v(\mathrm{O}-\mathrm{H})=3643 \mathrm{~cm}^{-1}\right)$. The similarities in these energies suggest that one intramolecular H-bond to the hydroxo ligand does not have a significant effect on the energy of this vibration. However, both these values are significantly larger than the $v(\mathrm{O}-\mathrm{H})=3614 \mathrm{~cm}^{-1}$ found for $\left[\mathrm{Mn}^{\mathrm{III}} \mathrm{H}_{3} \text { buea }(\mathrm{OH})\right]^{-}$, a complex that has three intramolecular H-bonds to the hydroxo ligand. We have also reported vibrational data on the analogous series of $\mathrm{Fe}(\mathrm{III})-\mathrm{OH}$ complexes and a similar trend was observed, although with a larger spread in values $\left(\left[\mathrm{Fe}(\mathrm{III}) \mathrm{H}_{3} \text { buea }(\mathrm{OH})\right]^{-}(\mathrm{V}(\mathrm{O}-\mathrm{H})\right.$ $\left.=3632 \mathrm{~cm}^{-1}\right),[\mathrm{Fe}(\mathrm{III}) \mathrm{H} \mathbf{1}(\mathrm{OH})]^{-}\left(v(\mathrm{O}-\mathrm{H})=3676 \mathrm{~cm}^{-1}\right)$, and $[\mathrm{Fe}(\mathrm{III}) \mathbf{0}(\mathrm{OH})]^{-}(\mathrm{v}(\mathrm{O}-\mathrm{H})=$ $\left.\left.3690 \mathrm{~cm}^{-1}\right)\right)[5 \mathrm{~b}]$.

\footnotetext{
${ }^{2}[\mathrm{Mn}(\mathrm{III}) \mathrm{H} \mathbf{1}(\mathrm{OH})]^{-}$could also be prepared by oxidation of $[\mathrm{Mn}(\mathrm{II}) \mathrm{H} \mathbf{1}(\mathrm{OH})]^{2-}$ with $\left[\mathrm{FeCp}_{2}\right] \mathrm{BF}_{4}$. Attempts to prepare the analogous $\mathrm{Mn}(\mathrm{III}) \mathrm{OH}$ complex using the ligand $\left[\mathrm{H}_{2} 2\right]^{3-}$ following similar procedures were unsuccessful.
} 


\subsection{Molecular structure of $\mathrm{K}[\mathrm{Mn}(\mathrm{III}) \mathrm{H} 1(\mathrm{OH})]$}

Crystals suitable for diffraction were obtained for $\mathrm{K}[\mathrm{Mn}(\mathrm{III})-\mathrm{H1}(\mathrm{OH})]$ and its structure was solved using X-ray diffraction methods (Fig. 6). Selected bond distances and angles are listed in Table 3. The manganese center has trigonal bipyramidal coordination geometry ( $\tau=$ $0.94)^{3}$ with the trigonal plane being defined by the deprotonated nitrogen atoms $\mathrm{N} 2, \mathrm{~N} 3$, and $\mathrm{N} 4$. The average $\mathrm{N}-\mathrm{Mn} 1-\mathrm{N}$ angle within the trigonal plane is $117.1(3)^{\circ}$, which agrees with the average bond angles of $117.3(1)^{\circ}$ and $118.2(1)^{\circ}$ found for $\mathrm{K}[\mathrm{Mn}(\mathrm{III}) \mathbf{0}(\mathrm{OH})]^{-}$and $\mathrm{K}\left[\mathrm{Mn}(\mathrm{III}) \mathrm{H}_{3} \text { buea }(\mathrm{OH})\right]^{-}$. The axial coordination sites in $[\mathrm{Mn}(\mathrm{III}) \mathrm{H} \mathbf{1}(\mathrm{OH})]^{-}$are occupied by the apical nitrogen $\mathrm{N} 1$ and hydroxo oxygen $\mathrm{O} 4$ with an N1-Mn1-O4 bond angle of $177.41(6)^{\circ}$. This bond angle is also similar to those reported for $\left[\mathrm{Mn}^{\mathrm{III}} \mathbf{0}(\mathrm{OH})\right]^{-}\left(177.7(2)^{\circ}\right)$ and $\left[\mathrm{Mn}^{\mathrm{III}} \mathrm{H}_{3} \text { buea }(\mathrm{OH})\right]^{-}\left(177.13(8)^{\circ}\right)$.

The complex $[\mathrm{Mn}(\mathrm{III}) \mathrm{H1}(\mathrm{OH})]^{-}$contains one intramolecular H-bond between $\mathrm{O} 4$ and N5-

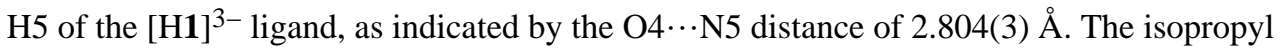
moieties are arranged such that their methyl groups are positioned inward toward the manganese center and thus complete the cavity structure around the $\mathrm{Mn}-\mathrm{OH}$ unit. Note that both methine $\mathrm{C}-\mathrm{H}$ groups are directed away from the metal center and have adopted a syn conformation with the amide carbonyl groups. A Mn1-O4 bond length of 1.846(1) A was observed in the $[\mathrm{Mn}(\mathrm{III}) \mathrm{H} \mathbf{1}(\mathrm{OH})]^{-}$, which is significantly shorter than the $1.872(2) \AA$ distance found for the nalogous bond in $\left[\mathrm{Mn}(\mathrm{III}) \mathrm{H}_{3} \text { buea }(\mathrm{OH})\right]^{-}$. Furthermore, $[\mathrm{Mn}(\mathrm{III}) \mathbf{0}(\mathrm{OH})]^{-}$which has no intramolecular $\mathrm{H}$-bonds has the shortest $\mathrm{Mn}-\mathrm{O}(\mathrm{H})$ bond length of 1.816(4) $\AA$. This difference in $\mathrm{Mn}-\mathrm{O}(\mathrm{H})$ bond lengths correlates with the number of intramolecular $\mathrm{H}$-bonds present in the complexes.

\section{Conclusion}

We presented results on the properties of $\mathrm{Mn}$ (II) and Fe(II) complexes of a series of tripodal ligands containing a varied number of H-bond donors. Our studies on the $\mathrm{Mn}$ (II) complexes demonstrated each complex is five-coordinate, with a coordinated acetate ion. The previously characterized structure of $\left[\mathrm{Mn}(\mathrm{II}) \mathrm{H}_{3} \text { buea }\left(\kappa^{1}-\mathrm{OAc}\right)\right]^{2-}$ revealed that an acetate ion is bonded within the H-bonding cavity formed by the urea groups of $\left[\mathrm{H}_{3} \mathrm{buea}\right]^{3-}$. This is in contrast to the chemistry observed with Fe(II) complexes of these ligands, in which no acetate ligand is present. It is unknown why the manganese complexes bind acetate while their Fe(II) analogs do not [14]. However, the presence of the acetato ligand appears to reinforce the cavity structure so that all arms of the tripod bind to a single metal ion. In the absence of an exogenous ligand, as was observed in the iron complexes, two of the complexes with urea groups formed dimers. One of the urea arms of $\left[\mathrm{H}_{3} \text { buea }\right]^{3-}$ and $\left[\mathrm{H}_{2} 2\right]^{3-}$ binds in a bidentate manner to a second Fe(II) center providing the necessary requirements to both primary and secondary coordination spheres. We also suggest that the dimeric structures of $\left[\mathrm{Fe}(\mathrm{II}) \mathrm{H}_{3} \text { buea }\right]_{2}{ }^{2-}$ and $\left[\mathrm{Fe}(\mathrm{II}) \mathrm{H}_{2} 2\right]_{2}{ }^{2-}$ are maintained in $\mathrm{MeCN}$ solution, a premise supported by comparison of their $\|$-mode EPR spectra in both solid and solution states to those of the monomeric K[Fe(II)0] salt. Finally, our investigations on

\footnotetext{
${ }^{3}$ For comparison, the $\tau$ values for $\mathrm{K}[\mathrm{Mn}(\mathrm{III}) \mathbf{0}(\mathrm{OH})]^{-}$and $\mathrm{K}\left[\mathrm{Mn}(\mathrm{III}) \mathrm{H}_{3} \text { buea( }(\mathrm{OH})\right]^{-}$are 0.87 and 0.71 , respectively $[12 \mathrm{~b}, 13]$.
} 
$[\mathrm{Mn}(\mathrm{III}) \mathrm{H1}(\mathrm{OH})]^{-}$further illustrates the effects of intramolecular $\mathrm{H}$-bonds on the structural and physical properties of metal complexes.

\section{Acknowledgments}

We thank the National Institutes of Health, USA (GM050781) and National Science Foundation, USA (0738252) for financial support.

This work is dedicated to Alfred Werner on the 100th Anniversary of his Nobel Prize in Chemistry in 1913.

\section{References}

1. (a) Werner A. Ann Chem. 1912; 386:1.(b) Werner A. Ber Dtsch Chem Ges. 1912; 45:121.

2. Selected examples: Jameson GB, Molinaro FS, Ibers JA, Collman JP, Brauman JI, Rose E, Suslick KS. J Am Chem Soc. 1978; 100:6769.; Collman JP, Brauman JI, Doxsee KM, Halbert TR, Bunnenberg E, Linder RE, Lamar GN, Del Gaudio J, Lang G, Spartalian K. J Am Chem Soc. 1980; 102:4182.; Collman JP, Brauman JI, Iverson BL, Sessler JL, Morris RM, Gibson QH. J Am Chem Soc. 1994; 116:6245.; Momenteau M, Reed CA. Chem Rev. 1994; 94:659.; Wuenschell GE, Tetreau C, Lavalette D, Reed CA. J Am Chem Soc. 1992; 114:3346.; Chang CK, Liang Y, Avilés G, Peng SM. J Am Chem Soc. 2001; 123:4191.; Yeh CY, Chang CJ, Nocera DG. J Am Chem Soc. 2001; 123:1513. [PubMed: 11456732] ; Some non-heme examples from Rivas and Berreau: Mareques-Rivas JC, Prabaharan R, de Rosales RTM. Chem Commun. 2004:76.; Berreau LM, Allred RA, Makowski Grzyska MM, Arif AM. Chem Commun. 2000:1423.; Berreau LM, Makowska MM, Grzyska MM, Arif AM. Inorg Chem. 2001; 40:2212. [PubMed: 11327890] ; Sigman JA, Kim HK, Zhao X, Carey JR, Lu Y. Proc Acad Natl Sci USA. 2003; 100:3629.; Lu Y. Inorg Chem. 2006; 45:9930. [PubMed: 17140190] ; Lu Y, Yeung N, Sieracki N, Marshall NM. Nature. 2009; 460:855. [PubMed: 19675646] ; Lu Y, Berry SM, Pfister TD. Chem Rev. 2001; 101:3047. [PubMed: 11710062] ; Natale D, Mareque-Rivas JC. Chem Commun. 2008:425.

3. (a) Shook RL, Borovik AS. Chem Commun. 2008:6095.(b) Borovik AS. Acc Chem Res. 2005; 38:54. [PubMed: 15654737]

4. Shook RL, Borovik AS. Inorg Chem. 2010; 49:3646. and references therein. [PubMed: 20380466]

5. (a) Lucas RL, Zart MK, Murkherjee J, Sorrell TN, Powell DR, Borovik ASJ. Am Chem Soc. 2006; 128:15476.(b) Mukherjee J, Lucas RL, Zart MK, Powell DR, Day VW, Borovik AS. Inorg Chem. 2008; 47:5780. [PubMed: 18498155]

6. Connelly NG, Geiger WE. Chem Rev. 1996; 96:877. [PubMed: 11848774]

7. Shirin Z, Hammes BS, Young VG Jr, Borovik AS. J Am Chem Soc. 2000; 122:1836.

8. Ray M, Golombek AP, Hendrich MP, Young VG Jr, Borovik AS. J Am Chem Soc. 1996; 118:6084.

9. Macbeth CE, Hammes BS, Young VG Jr, Borovik AS. Inorg Chem. 2001; 40:4733. [PubMed: 11511223]

10. (a) Addison AW, Rao TN, Reedijk J, Rijn JV, Vershoor GC. J Chem Soc Dalton Trans. 1984:1349.(b) Atwood, David A.; Hutchison, Aaron R.; Zhang, Yuzhong. Structure and Bonding: Compounds Containing Five-Coordinate Group 13 Elements. Vol. 105. Springer-Verlag; Berlin, Hiedelberg: 2003.

11. Zart MK, Sorrell TN, Powell D, Borovik AS. Dalton Trans. 2003:1986.

12. Other examples of Fe complexes with the ligand $\left[\mathrm{H}_{3} \text { buea }\right]^{3-}$ and $\left[\mathrm{H}_{2} 2\right]^{3-}$ MacBeth $\mathrm{CE}$, Golombek AP, Young VG, Yang C, Kuczera K, Hendrich MP, Borovik AS. Science. 2000; 289:938. [PubMed: 10937994] ; MacBeth CE, Gupta R, Mitchell-Koch KR, Young VG, Lushington GH, Thompson WH, Hendrich MP, Borovik AS. J Am Chem Soc. 2004; 126:2556. [PubMed: 14982465] ; Larsen PL, Gupta R, Powell DR, Borovik AS. J Am Chem Soc. 2004; 126:6522. [PubMed: 15161258] ; Lacy DC, Gupta R, Stone KL, Greaves J, Ziller JW, Hendrich MP, Borovik AS. J Am Chem Soc. 2010; 132:12188. [PubMed: 20704272] ; Lucas RL, Powell DR, Borovik AS. J Am Chem Soc. 2005; 127:11596. [PubMed: 16104724]

13. Shirin Z, Young VG Jr, Borovik AS. Chem Commun. 1997:1967. 
14. Ng GK-Y, Ziller JW, Borovik AS. Inorg Chem. 2011; 50:7922. [PubMed: 21793511] . In this system, we observed differences in coordination chemistry with $\mathrm{Mn}(\mathrm{II}), \mathrm{Fe}(\mathrm{II})$, and $\mathrm{Co}(\mathrm{II})$ despite the fact that the same ligand was used. 
<smiles>CC(C)(C)NC(=O)N1CCN(C(=O)NC(C)(C)C)N(C(=O)NC(C)(C)C)CC1</smiles>

$\left[\mathrm{M}^{\prime \prime \prime} \mathrm{H}_{3}\right.$ buea]<smiles>CC(C)(C)NC(=O)N1CCN(C(=O)N2CCN(C(=O)NC(C)(C)C)CC2)CC1</smiles>

$\left[\mathrm{M}^{\prime \prime \prime} \mathrm{H}_{2} 2\right]$

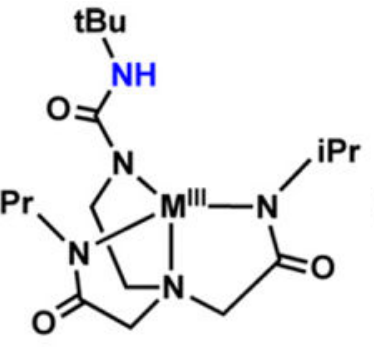

[M"I'H1]<smiles>CC(C)N1C(=O)N2N(C(C)C)C(=O)CN1C(=O)N2C(C)C</smiles>

$\left[\mathrm{M}^{1 ! \prime} 0\right]$

Fig. 1.

The series of metal complexes with varying number of intramolecular H-bond donors used in this study. 


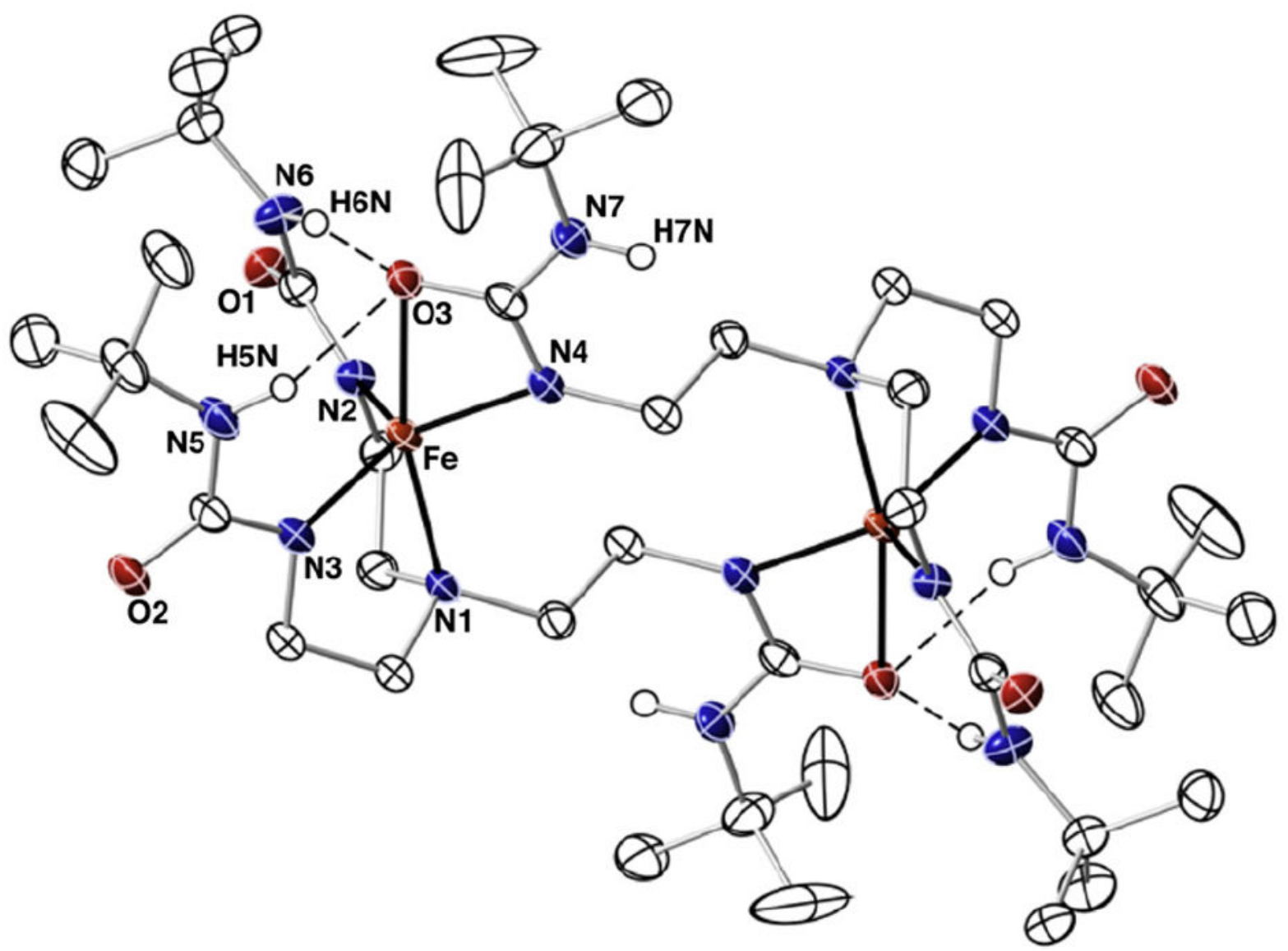

Fig. 2.

Thermal ellipsoid diagram for the molecular structure of $\left[\mathrm{Fe}(\mathrm{II}) \mathrm{H}_{3} \mathrm{buea}\right]_{2}{ }^{2-}$. Only the urea hydrogen atoms are shown for clarity. Thermal ellipsoids are drawn at the $50 \%$ probability level. 


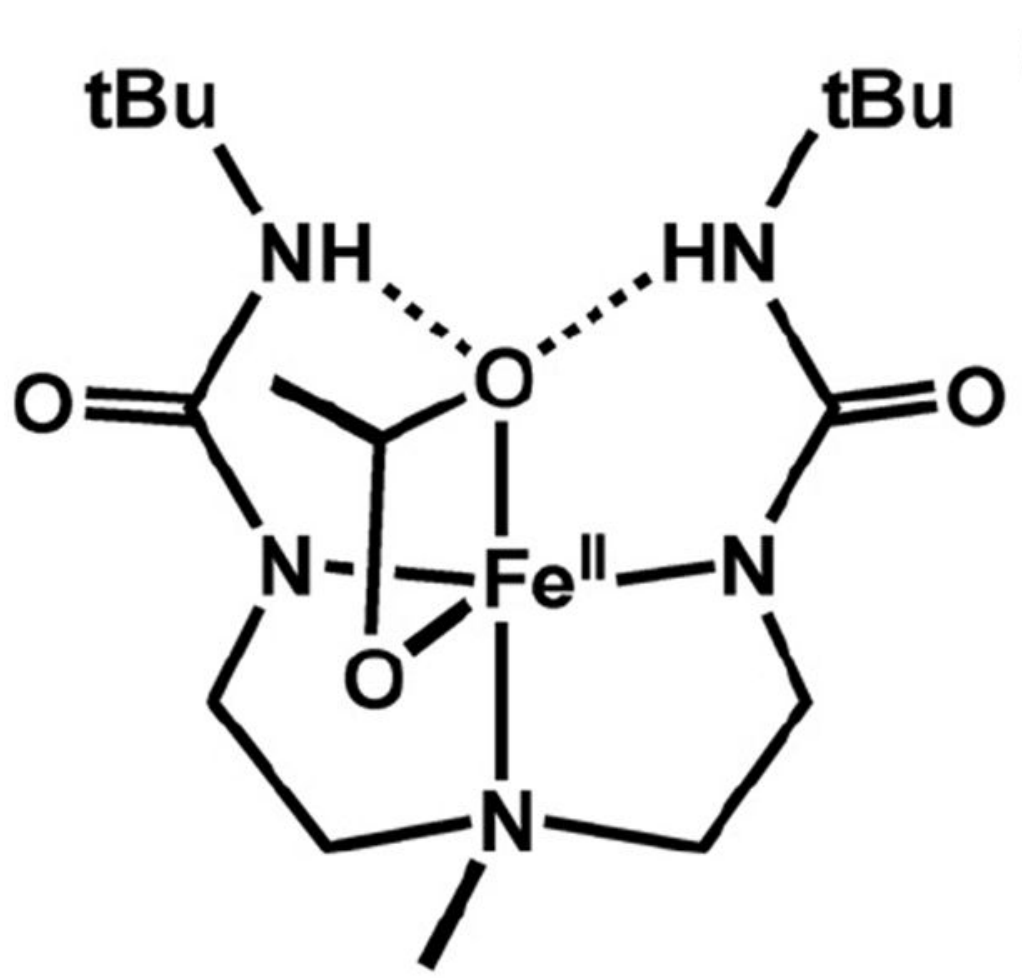

\section{$\left[\mathrm{Fe}(\mathrm{II}) \mathrm{H}_{2} \mathrm{buma}\left(\mathrm{\kappa}^{2}-\mathrm{OAc}\right)\right]^{-}$}

Fig. 3.

Representation of the structure for $\left[\mathrm{Fe}(\mathrm{II}) \mathrm{H}_{2} \text { buma }\left(\kappa^{2}-\mathrm{OAc}\right)\right]^{-}$. 


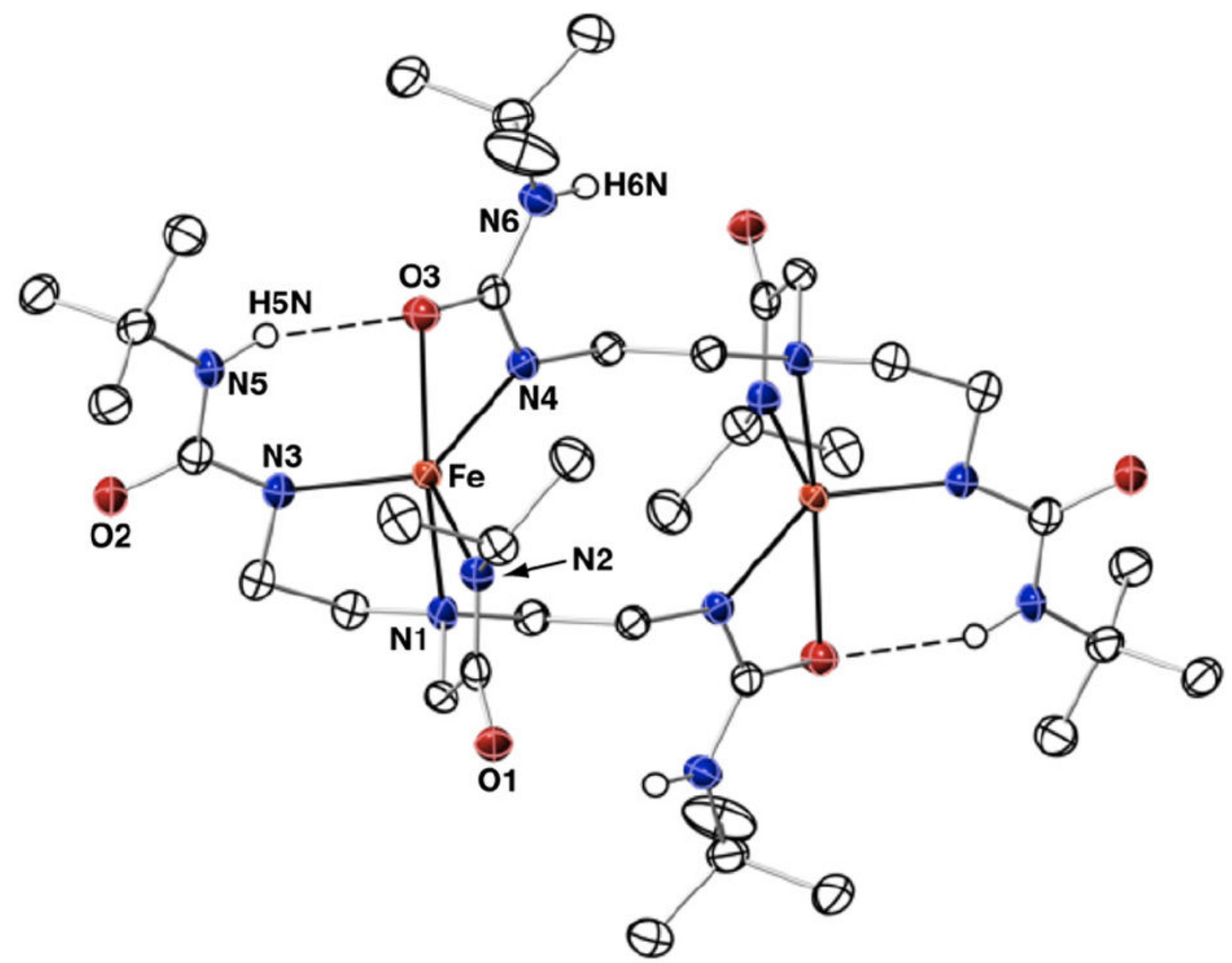

Fig. 4.

Thermal ellipsoid diagram for the molecular structure of $\left[\mathrm{Fe}(\mathrm{II}) \mathrm{H}_{2} 2\right]_{2}{ }^{2-}$. Only the urea hydrogen atoms are shown for clarity. Thermal ellipsoids are drawn at the $50 \%$ probability level. 

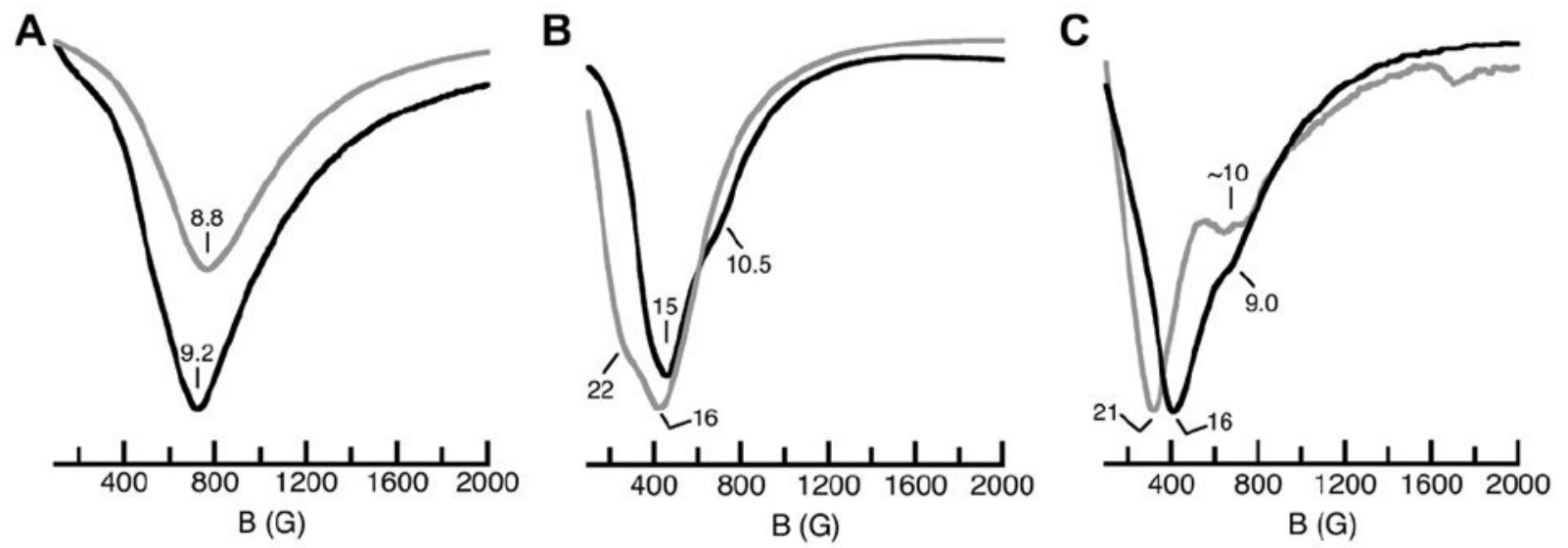

Fig. 5.

$\|$-mode EPR spectra for $[\mathrm{Fe}(\mathrm{II}) 0]^{-}(\mathrm{A}),\left[\mathrm{Fe}(\mathrm{II}) \mathrm{H}_{3} \text { buea }\right]_{2}{ }^{2-}(\mathrm{B})$, and $\left[\mathrm{Fe}(\mathrm{II}) \mathrm{H}_{2} 2\right]^{2-}(\mathrm{C})$ measured at $4 \mathrm{~K}$. Gray spectra are from solid-state samples and black spectra are from frozen acetonitrile solutions. 


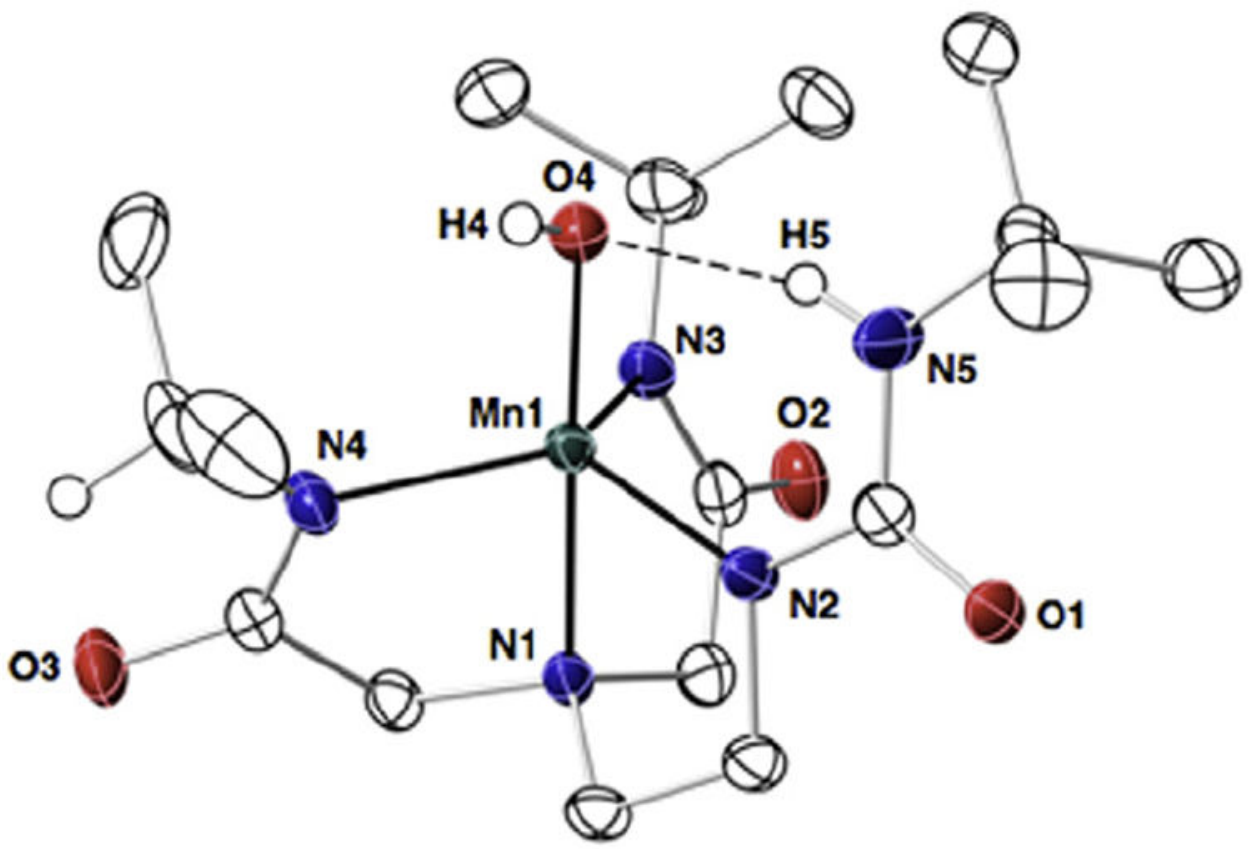

Fig. 6.

Thermal ellipsoid diagram for the molecular structure of $[\mathrm{Mn}(\mathrm{III}) \mathrm{H1}(\mathrm{OH})]^{-}$. Only the urea, hydroxo, and methine hydrogen atoms are shown for clarity. Thermal ellipsoids are drawn at the $50 \%$ probability level. 


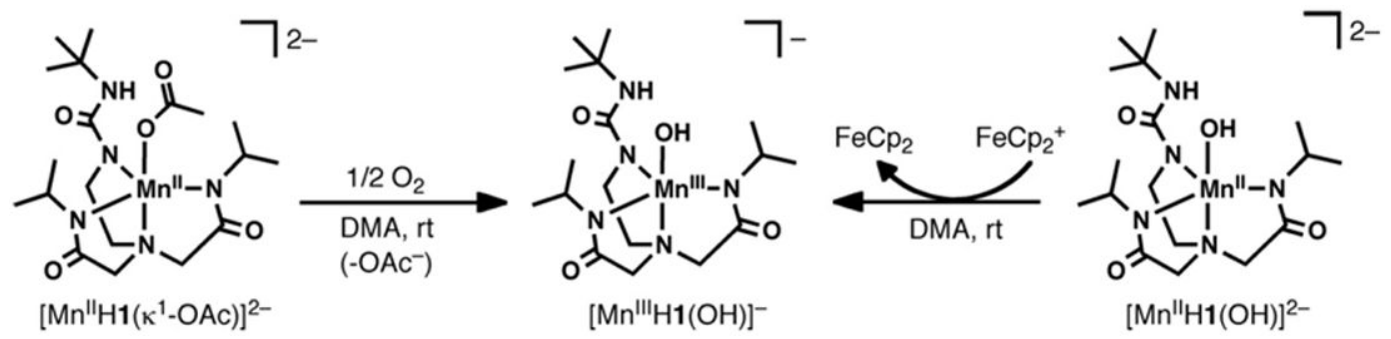

Scheme 1.

Preparative routes to $[\mathrm{Mn}(\mathrm{III}) \mathrm{H} 1(\mathrm{OH})]^{-}$. 


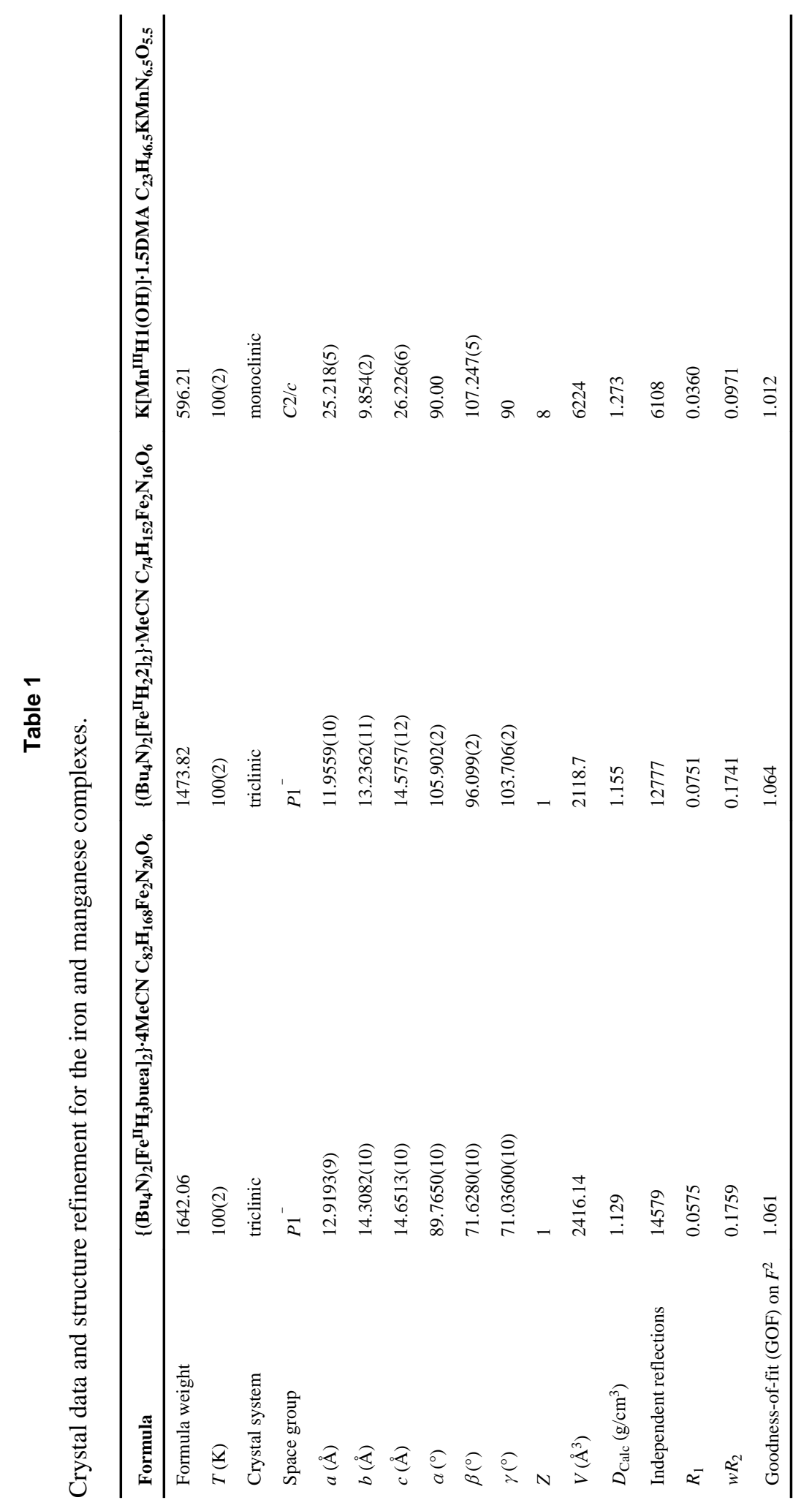

Polyhedron. Author manuscript; available in PMC 2014 June 03. 
Table 2

Selected metrical data for $\left[\mathrm{Fe}^{\mathrm{II}} \mathrm{H}_{3} \text { buea }\right]_{2}{ }^{2-}$ and $\left[\mathrm{Fe}^{\mathrm{II}} \mathrm{H}_{2} 2\right]_{2}{ }^{2-}$.

\begin{tabular}{|c|c|c|}
\hline \multicolumn{3}{|c|}{$\left[\mathrm{Fe}(\mathrm{II}) \mathrm{H}_{3} \text { buea }\right]_{2}{ }^{2-}\left[\mathrm{Fe}(\mathrm{II}) \mathrm{H}_{2} 2\right]_{2}{ }^{2-}$} \\
\hline \multicolumn{3}{|c|}{ Bond distances $(\AA)$} \\
\hline $\mathrm{Fe}-\mathrm{O} 3$ & $2.388(1)$ & $2.335(2)$ \\
\hline $\mathrm{Fe}-\mathrm{N} 1$ & $2.570(1)$ & $2.231(2)$ \\
\hline $\mathrm{Fe}-\mathrm{N} 2$ & $2.034(1)$ & $2.042(2)$ \\
\hline $\mathrm{Fe}-\mathrm{N} 3$ & $2.030(1)$ & $2.025(2)$ \\
\hline $\mathrm{Fe}-\mathrm{N} 4$ & $2.041(1)$ & $2.060(2)$ \\
\hline $\mathrm{Fe} \cdots \mathrm{Fe}$ & 6.119 & 5.950 \\
\hline$\tau$ & 0.74 & 0.71 \\
\hline \multicolumn{3}{|c|}{ Bond angles $\left({ }^{\circ}\right)$} \\
\hline $\mathrm{N} 1-\mathrm{Fe}-\mathrm{O} 3$ & $166.70(5)$ & $168.96(7)$ \\
\hline $\mathrm{N} 3-\mathrm{Fe}-\mathrm{N} 4$ & $122.41(6)$ & $126.60(9)$ \\
\hline $\mathrm{N} 4-\mathrm{Fe}-\mathrm{N} 2$ & $122.34(5)$ & $118.77(9)$ \\
\hline $\mathrm{N} 2-\mathrm{Fe}-\mathrm{N} 3$ & $115.08(6)$ & $114.46(9)$ \\
\hline
\end{tabular}


Table 3

Selected bond distances and angles for $[\mathrm{Mn}(\mathrm{III}) \mathrm{H} 1(\mathrm{OH})]^{-}$.

\begin{tabular}{ll}
\hline$[\mathrm{Mn}(\mathrm{III}) \mathbf{H 1}(\mathbf{O H})]^{-}$ & \\
\hline Distances $(\AA)$ & \\
$\mathrm{Mn}-\mathrm{O} 4$ & $1.846(1)$ \\
$\mathrm{Mn}-\mathrm{N} 1$ & $2.028(2)$ \\
Avg. $\mathrm{Mn}-\mathrm{N}_{\mathrm{eq}}$ & $2.048(2)$ \\
$\mathrm{N} 5 \cdots \mathrm{O} 4$ & $2.804(2)$ \\
Angles $\left(^{\circ}\right)$ & \\
$\mathrm{N} 1-\mathrm{Mn}-\mathrm{O} 4$ & $177.41(6)$ \\
$\mathrm{N} 2-\mathrm{Mn}-\mathrm{N} 3$ & $116.92(6)$ \\
$\mathrm{N} 3-\mathrm{Mn}-\mathrm{N} 4$ & $113.84(6)$ \\
$\mathrm{N} 4-\mathrm{Mn}-\mathrm{N} 2$ & $121.24(7)$ \\
Avg. N-Mn-N & $117.3(1)$ \\
$\tau$ & 0.94 \\
\hline
\end{tabular}

